\title{
OD REDAKCJI
}

W dniach 30-31 maja 2017 r. w Centrum Szkoleniowo-Konferencyjnym Uniwersytetu Łódzkiego odbyła się Międzynarodowa Konferencja Naukowa „Problemy semantyki i stylistyki tekstu”, zorganizowana przez Zakład Językoznawstwa Instytutu Rusycystyki UŁ. Było to szóste z kolei spotkanie filologów, dotyczące zagadnień związanych z szeroko pojmowaną semantyką i stylistyką tekstu zarówno w ujęciu synchronicznym, jak i diachronicznym. Co istotne, po raz pierwszy w ramach Konferencji przeprowadzona została jednodniowa sesja naukowa poświęcona życiu i twórczości Vladimira Nabokova. Ogółem w konferencji wzięło udział 25 osób reprezentujących ośrodki naukowe w Polsce (Uniwersytet Jagielloński, Uniwersytet Wrocławski, Katolicki Uniwersytet Lubelski, Uniwersytet Warszawski, Uniwersytet Szczeciński, Uniwersytet Kazimierza Wielkiego w Bydgoszczy, Uniwersytet Śląski, Uniwersytet Przyrodniczo-Humanistyczny w Siedlcach, Uniwersytet Łódzki, Uniwersytet Gdański) i za granicą (Rosja, Ukraina, Niemcy, Kazachstan).

Piętnasty tom czasopisma „Folia Linguistica Rossica” obejmuje rezultaty badań naukowych zaprezentowane w ramach Konferencji. W pierwszej części, zatytułowanej zgodnie $\mathrm{z}$ jej głównym hasłem, zgromadzonych zostało piętnaście artykułów dotyczących zjawisk językowych z zakresu słowotwórstwa, leksykografii, semantyki, stylistyki i onomastyki w ujęciu pragmatycznym i kognitywnym. Ich autorzy sięgają do problemów lingwistycznych o charakterze ogólnojęzykowym i żargonowym. Ponadto znaczna część prac dotyczy zagadnień związanych z przekładem tekstów literackich i poszczególnych jednostek leksykalnych oraz odnoszących się do problemów nauczania języków obcych na tle kultury ich obszaru. Analizie poddane zostały teksty literackie, publicystyczne, reklamowe i filmowe.

Druga część niniejszego tomu poświęcona została problematyce związanej ze specyfiką twórczości wielkiego rosyjsko-amerykańskiego pisarza - Vladimira Nabokova. Prezentowane artykuły odzwierciedlają różnorodność badawczych zainteresowań ich autorów i jednocześnie wieloaspektowość twórczości pisarza. Charakterystyczne dla niego zjawisko synestezji omówione zostało zarówno z punktu widzenia związanych z nimi barw i problemów ich przekładu, jak i z punktu widzenia odmian języka figuratywnego. Innym typowym dla Nabokova aspektem jego twórczości są znaczące nazwy własne jako element gry z czytelnikiem, ukazane i omówione w szerokim ujęciu interdyscyplinarnym. Uwadze czytelnika polecamy również artykuł poświęcony refleksjom pisarza i sposobom konstrukcji świata przedstawionego w jego tekstach o charakterze autobiograficznym. 
Przedstawione artykuły są świadectwem ciekawych i różnorodnych poszukiwań badawczych i udanych rozwiązań metodycznych. Zaproponowane przez autorów zagadnienia i obserwacje staną się z pewnością inspiracją dla dalszych poszukiwań filologicznych.

Anna Ginter 